Article

\title{
Coal Fly Ash as Raw Material for Immobilization of Sr-Contaminated Soil by Microwave Heating: Mechanism and Performance
}

\author{
Yupeng Xie ${ }^{1, *}$, Ailian Zhu ${ }^{1}$, Min Chen ${ }^{1}$, Bing Dai ${ }^{1} \mathbb{D}$, Bin Wang ${ }^{2}$ and Yong Liu ${ }^{1, *}$ \\ 1 School of Resource Environment and Safety Engineering, University of South China, \\ Hengyang 421001, China; zhuailianailian@163.com (A.Z.); chenm962387@163.com (M.C.); \\ daibingusc@usc.edu.cn (B.D.) \\ 2 Hunan NO.4 Engineering Co., Ltd., Changsha 410083, China; wangbinking007@163.com \\ * Correspondence: xieyupeng@usc.edu.cn (Y.X.); liuyong81668@163.com (Y.L.); Tel.: +86-15886414635 (Y.X.); \\ $+86-13507341111$ (Y.L.)
}

check for updates

Citation: Xie, Y.; Zhu, A.; Chen, M.; Dai, B.; Wang, B.; Liu, Y. Coal Fly Ash as Raw Material for Immobilization of Sr-Contaminated Soil by Microwave Heating: Mechanism and Performance. Crystals 2022, 12, 55. https://doi.org/10.3390/ cryst12010055

Academic Editors: Dawei Wang, Andrey Prokofiev and Zhao Zhang

Received: 12 November 2021 Accepted: 27 December 2021 Published: 31 December 2021

Publisher's Note: MDPI stays neutral with regard to jurisdictional claims in published maps and institutional affiliations.

Copyright: (c) 2021 by the authors Licensee MDPI, Basel, Switzerland. This article is an open access article distributed under the terms and conditions of the Creative Commons Attribution (CC BY) license (https:// creativecommons.org/licenses/by/ $4.0 /)$.

\begin{abstract}
In this work, coal fly ash, hereinafter CFA is proposed to work as raw material for immobilization of Sr-contaminated soil by microwave sintering in the path towards resource utilization of solid waste. The immobilization mechanism and performance was systemically investigated through phase evolution, microstructure, elemental distribution, and physical properties. The results shown that the $\mathrm{Sr}$ could be incorporated into feldspar strontian $\left(\mathrm{SrAl}_{2} \mathrm{Si}_{2} \mathrm{O}_{8}\right)$ at $1300{ }^{\circ} \mathrm{C}$ for $30 \mathrm{~min}$. Moreover, the maximum solid solubility of $\mathrm{SrSO}_{4}$ was more than $30 \mathrm{wt}$.\%. The $\mathrm{Sr}$ was homogeneously distributed in the sintered matrices without substantial enrichment. The sintered matrix exhibited high density $\left(2.53 \mathrm{~g} / \mathrm{cm}^{3}\right)$. Thus, microwave heating coupled with CFA could provide a new method for immobilization of Sr-contaminated soil in case of the spent nuclear reprocessing cycle in nuclear power plants or a nuclear accident emergency.
\end{abstract}

Keywords: Sr-contaminated soil; microwave heating; feldspar strontian; microstructure

\section{Introduction}

Strontium $\left({ }^{90} \mathrm{Sr}\right)$ with a long half-life of approximately 30 years is a typical fission product with high radioactivity and radiotoxicity generated from the spent nuclear reprocessing cycle in nuclear power plants [1,2]. Importantly, once the nuclide migrates into water or air through the soil, it will pose a great threat to human health and the surrounding environment. In recent years, especially after the nuclear accident in Fukushima, the safety of nuclear energy has been a greater public consideration [3,4]. In the Fukushima nuclear accident, large amounts of radioactive ${ }^{90} \mathrm{Sr}$ were released and deposited in the soil, resulting in chronic soil pollution $[4,5]$. Therefore, it is urgent to safely dispose of Sr-contaminated soil for the sustainable development of the nuclear industry. In the last decades, borosilicate glass is the only waste form applied at industrial scale [6,7]. Due to superior stable nature, extensive researches suggest that ceramic waste forms could improve the long-term aqueous performance in comparison with the vitrified matrices [8,9]. Meanwhile, CFA, the major solid waste from the coal-fired thermal power plants, also has caused a lot of environmental problems, such as decreasing the agricultural acreage and polluting the groundwater and atmosphere [10]. It is reported that approximately 1000 million tons of CFA are produced annually around the world. Unfortunately, its utilization ratio remains below $50 \%$ [11]. Abundance in silica $\left(\mathrm{SiO}_{2}\right)$ and alumina $\left(\mathrm{Al}_{2} \mathrm{O}_{3}\right)$, in the path towards resource utilization of solid waste, CFA can be selected as a potential source of raw materials to sinter glass and ceramic [12,13]. As an emerging heating method, microwave sintering has the advantages of volumetric energy absorption, rapid heating rate, and low energy consumption when compared to conventional sintering methods [14]. Extensive previous 
researches have been carried out to explore immobilization of radionuclide-contaminated soil via microwave heating, and the curing mechanism and feasibility are proven [15-18]. Furthermore, microwave sintering substantially improved the microstructural uniformity and macroscopic properties of the final cured product [19].

Inspired by the above, herein, microwave heating coupled with CFA was employed to dispose of Sr-contaminated soil. Phase evolution and microstructure with the elevation of sintering temperature were systematically studied. The existing form, ultimate solid solubility, and immobilization mechanism of strontium in the sintered matrix was investigated through X-ray diffraction (XRD, $X^{\prime}$ Per Pro, Almelo, Netherlands), Fourier transform infrared spectroscopy (FT-IR, IRAffinity-1S, Kyoto, Japan), scanning electron microscope (SEM, TESCAN MIRA4, Brno, Czech Republic), and transmission electron microscope (TEM, Talos F200X G2, Brno, Czech Republic).

\section{Materials and Methods}

\subsection{Materials}

The CFA and $\mathrm{SrSO}_{4}$ powders (AR grade) were utilized as the starting materials. The CFA was sourced from the thermal power plant in Hunan, China. After being oven-dried at $105^{\circ} \mathrm{C}$ for $24 \mathrm{~h}$ to remove absorbed water, the CFA was passed through a 200-mesh screen. The phase composition of the CFA was characterized by X-ray diffraction (XRD), as shown in Figure 1. Moreover, the chemical composition of the preprocessed CFA characterized by X-ray fluorescence (XRF) was present in Table 1. It can be observed that the CFA has high contents of $\mathrm{SiO}_{2}(57.06 \mathrm{wt} . \%)$ and $\mathrm{Al}_{2} \mathrm{O}_{3}(29.13 \mathrm{wt} . \%)$ with only trace amounts of other oxides and carbon.

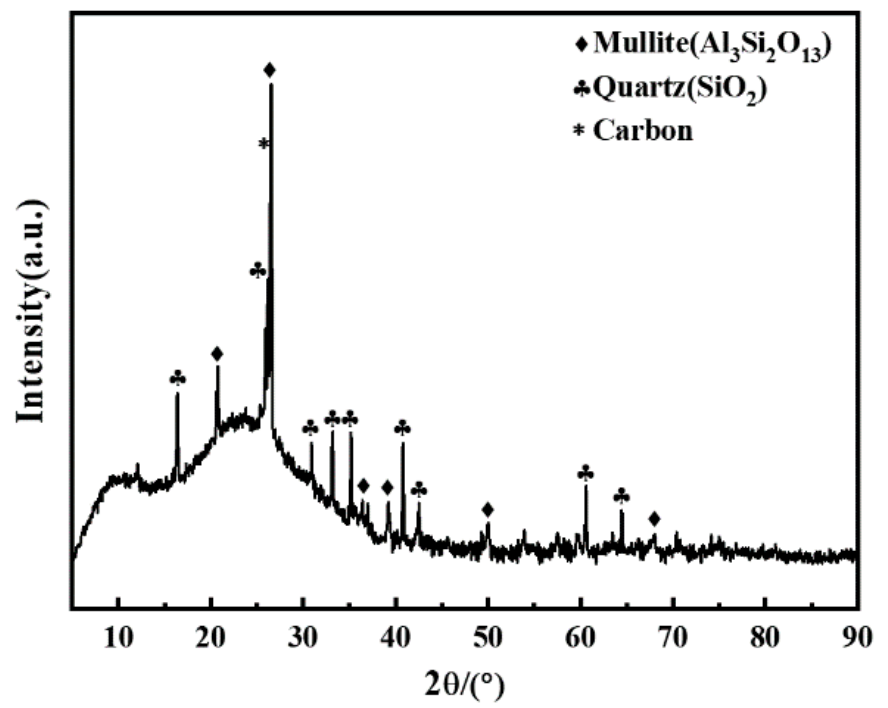

Figure 1. XRD pattern of the CFA.

Table 1. Chemical composition of coal fly ash determined by XRF (wt.\%).

\begin{tabular}{ccccccccccccc}
\hline & $\mathrm{Al}_{2} \mathrm{O}_{3}$ & $\mathrm{SiO}_{2}$ & $\mathrm{CaO}$ & $\mathrm{K}_{2} \mathrm{O}$ & $\mathrm{Fe}_{2} \mathrm{O}_{3}$ & $\mathrm{Na}_{2} \mathrm{O}$ & $\mathrm{MgO}$ & $\mathrm{TiO}_{2}$ & $\mathrm{SO}_{3}$ & $\mathrm{P}_{2} \mathrm{O}_{5}$ & $\mathrm{ZnO}_{2}$ \\
\hline CFA & 29.13 & 57.06 & 3.05 & 2.88 & 2.36 & 1.15 & 1.11 & 1.11 & 1.02 & 0.522 & 0.465 \\
\hline
\end{tabular}

\subsection{Experiment Procedures}

The refined CFA was mixed with $\mathrm{SrSO}_{4}$ in equal proportion $(0 \mathrm{wt} . \%, 5 \mathrm{wt} . \%, 10 \mathrm{wt} . \%$, 15 wt. $\%$, 20 wt. \%, 25 wt. \%, and 30 wt.\%) to obtain Sr-contaminated soil, denoted as S0, S5, S10, S15, S20, S25, and S30, respectively. Subsequently, the mixtures were wet ground in a mortar with alcohol as the medium. After being ground uniformly, the homogenized mixtures were dried again and then pressed into pellets of $10 \mathrm{~mm}$ in diameter and $3 \mathrm{~mm}$ in thickness by the cold isostatic pressing under $200 \mathrm{MPa}$. Finally, the samples held by 
alumina crucibles were sintered at $1100{ }^{\circ} \mathrm{C}, 1200{ }^{\circ} \mathrm{C}$, and $1300^{\circ} \mathrm{C}$ for $30 \mathrm{~min}$ in a microwave muffle furnace under air atmosphere. The samples were firstly heated at $800^{\circ} \mathrm{C}$ for $60 \mathrm{~min}$ to burn out the carbon and remove volatile components. As the temperature below $1000{ }^{\circ} \mathrm{C}$, the heating rate was set to $20^{\circ} \mathrm{C} / \mathrm{min}$ and then reduced to $10^{\circ} \mathrm{C} / \mathrm{min}$ as the temperature beyond $1000{ }^{\circ} \mathrm{C}$. After being maintained at target temperatures for $30 \mathrm{~min}$, the sintered matrices were naturally cooled down to room temperature. The whole experimental process was shown in Figure 2.

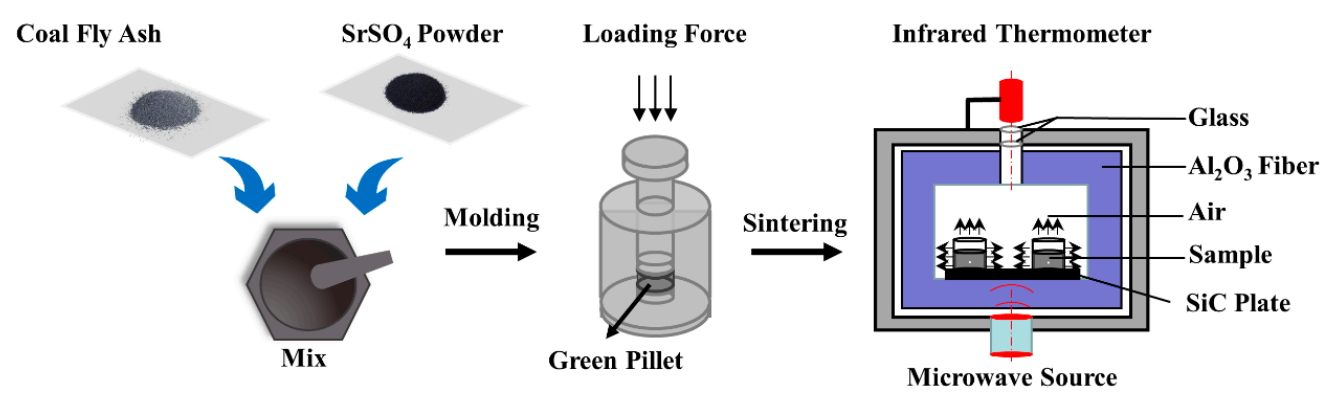

Figure 2. Schematic of the experimental process.

\subsection{Characterization}

The compositions of the sintered compacts were determined by X-ray diffraction (XRD, $\mathrm{X}^{\prime}$ Per Pro, Almelo, Netherlands) with $\mathrm{Cu}-\mathrm{K} \alpha$ radiation operating at $45 \mathrm{kV}$ and $40 \mathrm{~mA}$ in the $10^{\circ}-80^{\circ}(2 \theta)$ range. The detailed structure of the sintered forms was further confirmed by a Fourier transform infrared spectroscopy (FT-IR, PE Spectrum One, Waltham, MA, USA). The micromorphology and elemental distribution of the sintered sample was observed by a scanning electron microscope (SEM, TESCAN MIRA4, Brno, Czech Republic).

The bulk density of the sample was measured by a densitometer (MDJ-200S, Dongguan, China) with the Archimedes method at $24{ }^{\circ} \mathrm{C}$, and deionized water was used as the immersion medium. The open porosity was calculated using the following Formula (1) [20]:

$$
\mathrm{P}_{\mathrm{o}}=\frac{M_{3}-M_{1}}{M_{3}-M_{2}} .
$$

where $M_{1}$ is the dry mass of the sample, $M_{2}$ is the mass of sample who is suspended in deionized water, and $M_{3}$ is the mass of the sample who is fully immersed in deionized water and saturated water absorption.

\section{Results and Discussion}

\subsection{Phase Evolution Analysis}

Figure 3 presents the XRD patterns of as-sintered samples doped with $0-30 \mathrm{wt}$.\% of $\mathrm{SrSO}_{4}$ in the temperature range of $1100-1300{ }^{\circ} \mathrm{C}$ for $30 \mathrm{~min}$. Figure 3 a displays the XRD patterns of the sintered forms loading 0-30 wt.\% $\mathrm{SrSO}_{4}$ fabricated at $1100{ }^{\circ} \mathrm{C}$. Evidently, the $\mathrm{SrSO}_{4}$-related phase can be found in all the sintered matrices, indicating that the $\mathrm{SrSO}_{4}$ could not be immobilized in the sintered samples at $1100{ }^{\circ} \mathrm{C}$. As demonstrated in Figure $3 \mathrm{~b}$, the diffraction peaks of feldspar strontian $\left(\mathrm{SrAl}_{2} \mathrm{Si}_{2} \mathrm{O}_{8}\right)$ are detected with the elevation of sintering temperature. Moreover, the main crystalline phase transforms from mullite and sillimanite to feldspar strontian with increasing $\mathrm{SrSO}_{4}$, indicating that the $\mathrm{SrSO}_{4}$ could be incorporated in the sintered matrix. Analogous results are shown in Figure 3c. The difference is that, as the firing temperature increases from $1200^{\circ} \mathrm{C}$ to $1300^{\circ} \mathrm{C}$, the number of diffraction peaks of feldspar strontian increase. The diffraction peaks of quartz and sillimanite both decrease, which may be ascribed to the involvement of $\mathrm{SiO}_{2}$ and $\mathrm{Al}_{2} \mathrm{O}_{3}$ in the synthesis of $\mathrm{SrAl}_{2} \mathrm{Si}_{2} \mathrm{O}_{8}$. What is interesting in Figure $3 \mathrm{~b}$ is that a few diffraction peaks of $\mathrm{SrSO}_{4}$ are detected in the sintered samples at $1200{ }^{\circ} \mathrm{C}$ as the doping amount of $\mathrm{SrSO}_{4}$ increases to $20 \mathrm{wt}$ \% , which suggest that the maximum solid solubility of $\mathrm{SrSO}_{4}$ at $1200{ }^{\circ} \mathrm{C}$ is between $15 \mathrm{wt} . \%$ and $20 \mathrm{wt} . \%$. As the sintering temperature elevates to $1300{ }^{\circ} \mathrm{C}$, 
the $\mathrm{SrSO}_{4}$-related phase has not been found in all the sintered compacts, implying that the maximum solid solubility of $\mathrm{SrSO}_{4}$ at $1300{ }^{\circ} \mathrm{C}$ is over $30 \mathrm{wt} . \%$.
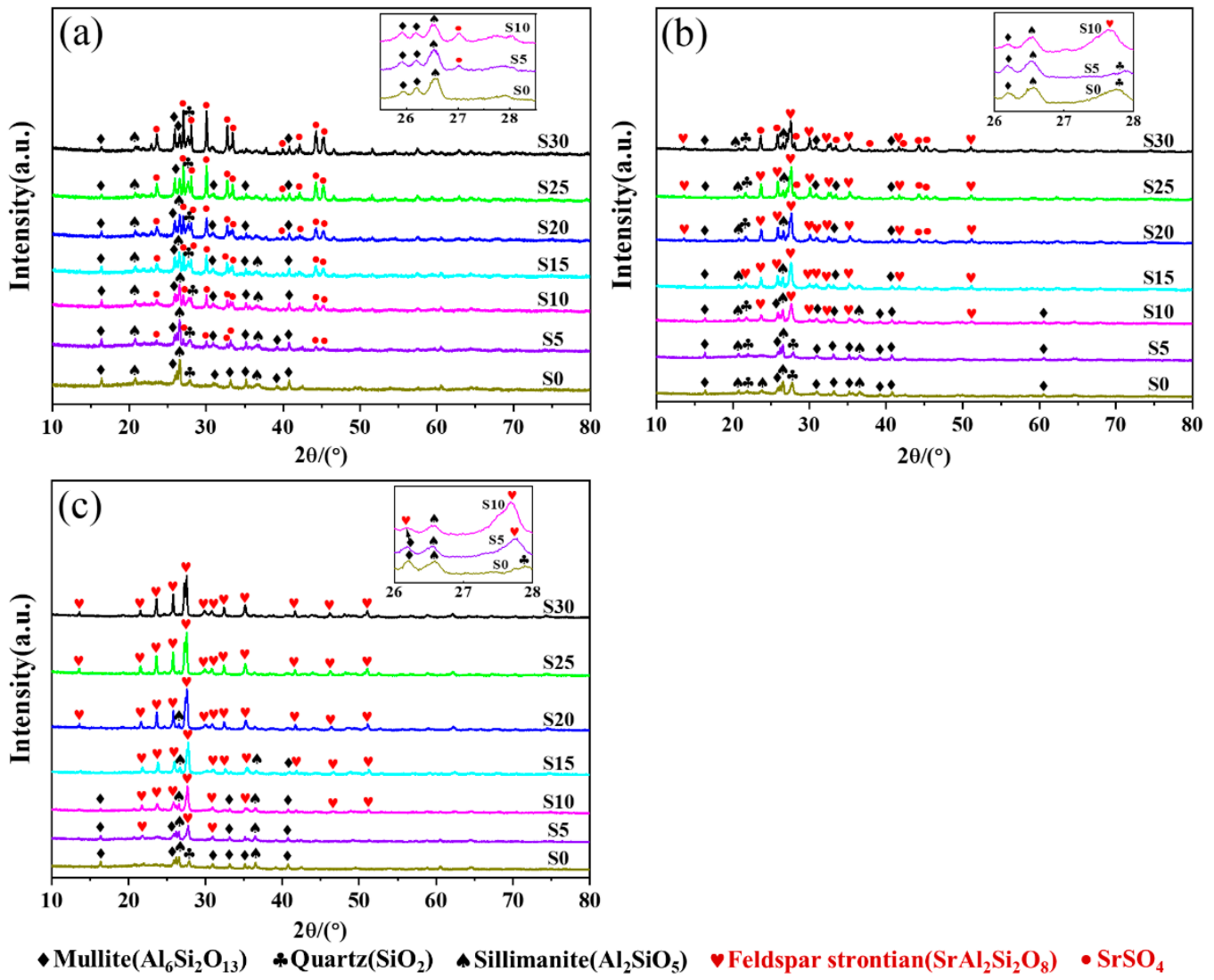

Figure 3. XRD patterns of the sintered forms doped with various amounts of $\mathrm{SrSO}_{4}$ prepared at different temperatures: (a) S0-S30 at $1100{ }^{\circ} \mathrm{C}$, (b) S0-S30 at $1200{ }^{\circ} \mathrm{C}$, and (c) S0-S30 at $1300{ }^{\circ} \mathrm{C}$.

\subsection{Microstructural Analysis}

The FT-IR technique is utilized to further reveal the immobilizing modes of Sr element in sintered matrix. Figure 4 a demonstrates the FT-IR spectra of the samples doped with various contents of $\mathrm{SrSO}_{4}$ prepared at $1300{ }^{\circ} \mathrm{C}$. Obviously, the main absorption peaks of the sintered samples are concentrated in the range of $400 \mathrm{~cm}^{-1}$ to $800 \mathrm{~cm}^{-1}$. The absorption peaks at $\sim 470 \mathrm{~cm}^{-1}$ and $\sim 456 \mathrm{~cm}^{-1}$ are attributed to the stretching vibrations of Si-O bonds [21,22]. The absorption peaks at $\sim 725 \mathrm{~cm}^{-1}$ and $\sim 673 \mathrm{~cm}^{-1}$ are ascribed to the stretching vibrations of $\mathrm{Si}-\mathrm{Al}(\mathrm{Si})$ and $\mathrm{Al}$ (Si)-O bonds, respectively [23]. The remaining part of the spectrum contains the modes of the bending vibrations of $\mathrm{O}-\mathrm{Si}(\mathrm{Al})-\mathrm{O}$ bonds (around $610 \mathrm{~cm}^{-1}$ and $576 \mathrm{~cm}^{-1}$ ) and O-Si-O bonds (near $540 \mathrm{~cm}^{-1}$ and $420 \mathrm{~cm}^{-1}$ ), and the stretching vibrations of $\mathrm{Sr}-\mathrm{O}$ bonds (near $540 \mathrm{~cm}^{-1}$ and $420 \mathrm{~cm}^{-1}$ ) [3]. Combined with the XRD results, the existence of $\mathrm{Sr}-\mathrm{O}$ bonds indicates that feldspar strontian is present in the sintered samples. Analogous results are shown in Figure $4 \mathrm{~b}$. The difference is that, the S-O bonds at $\sim 640 \mathrm{~cm}^{-1}$ are detected at $1100{ }^{\circ} \mathrm{C}$ and $1200{ }^{\circ} \mathrm{C}$, indicating the existence of $\mathrm{SrSO}_{4}$ [24]. As the firing temperature increases from $1200{ }^{\circ} \mathrm{C}$ to $1300{ }^{\circ} \mathrm{C}$, the S-O bonds are disappeared. It could be deduced $30 \mathrm{wt} . \% \mathrm{SrSO}_{4}$ could not be fully incorporated in the sintered matrices at $1100{ }^{\circ} \mathrm{C}$ and $1200{ }^{\circ} \mathrm{C}$, whereas the maximum solid solubility of $\mathrm{SrSO}_{4}$ at $1300{ }^{\circ} \mathrm{C}$ is over $30 \mathrm{wt} \%$. 

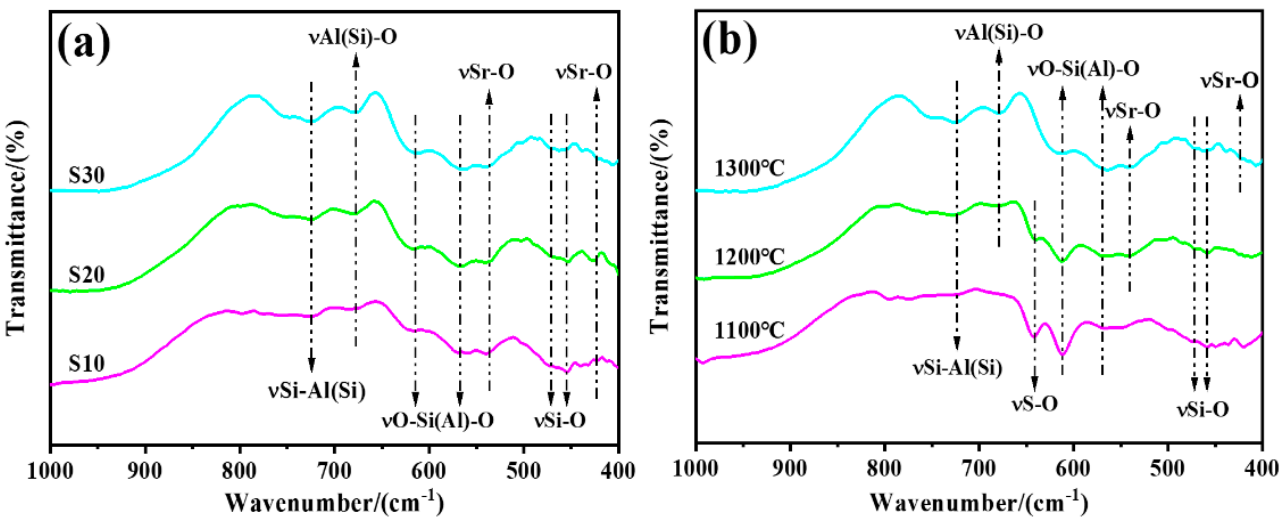

Figure 4. FT-IR spectra of the typical samples: (a) S0 S30 sintered at $1300{ }^{\circ} \mathrm{C}$, and (b) S30 sintered at $1100-1300^{\circ} \mathrm{C}$.

\subsection{Micromorphology Analysis}

The SEM and corresponding elemental mapping images of the typical samples are presented in Figures 5 and 6, respectively. As illustrated in Figure 5, many grains with dimensions of $5-10 \mu \mathrm{m}$ are observed. The ceramic is inferred to be feldspar strontian $\left(\mathrm{SrAl}_{2} \mathrm{Si}_{2} \mathrm{O}_{8}\right)$ according to the above XRD results. The corresponding elemental mapping of the main elements $(\mathrm{Sr}, \mathrm{Al}, \mathrm{Si}, \mathrm{O}$, and $\mathrm{S})$ is demonstrated in Figure 6. It is evident from Figure $6 \mathrm{a}, \mathrm{b}, \mathrm{d}, \mathrm{e}$ that the $\mathrm{S}$ element is distributed with obvious enrichment. It implies that $\mathrm{SrSO}_{4}$ could not be fully fixed under these conditions, which is consistent with the phase analysis results in Figure 3. On the contrary, all the elements are evenly distributed without obvious enrichment in Figure 6c,f. Combined with the above XRD analysis, the elemental mapping results are valuable to certify that at least $30 \mathrm{wt} . \% \mathrm{SrSO}_{4}$ could be successfully incorporated in the sintered samples obtained by microwave preparation at $1300{ }^{\circ} \mathrm{C}$ for $30 \mathrm{~min}$.
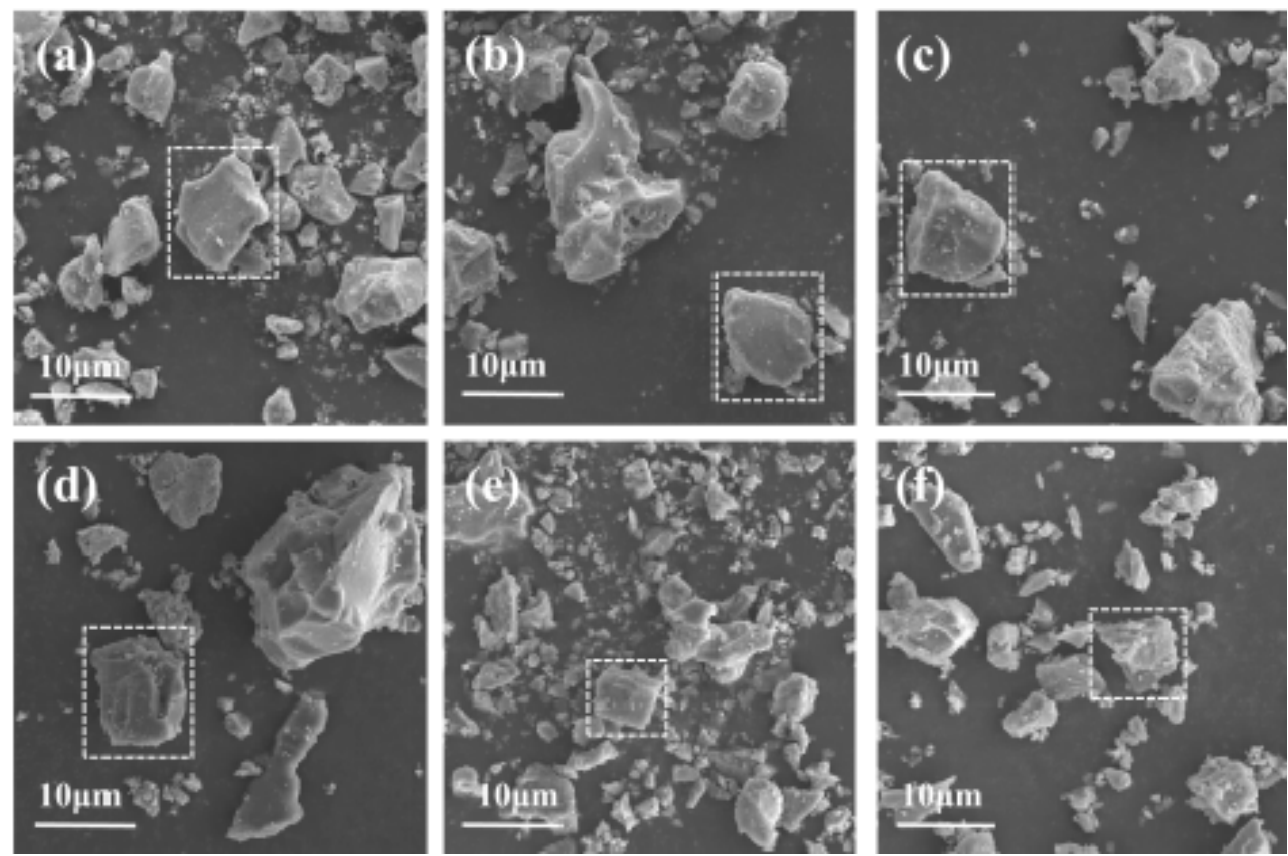

Figure 5. Microscope analyzed by SEM: (a) $1100{ }^{\circ} \mathrm{C}, 20 \mathrm{wt} \% \mathrm{SrSO}_{4}$, (b) $1200{ }^{\circ} \mathrm{C}, 20 \mathrm{wt} . \% \mathrm{SrSO}_{4}$, (c) $1300{ }^{\circ} \mathrm{C}, 20 \mathrm{wt} . \% \mathrm{SrSO}_{4}$, (d) $1100{ }^{\circ} \mathrm{C}, 30 \mathrm{wt} . \% \mathrm{SrSO}_{4}$, (e) $1200{ }^{\circ} \mathrm{C}, 30 \mathrm{wt} . \% \mathrm{SrSO}_{4}$, and (f) $1300{ }^{\circ} \mathrm{C}$, 30 wt. $\% \mathrm{SrSO}_{4}$. 


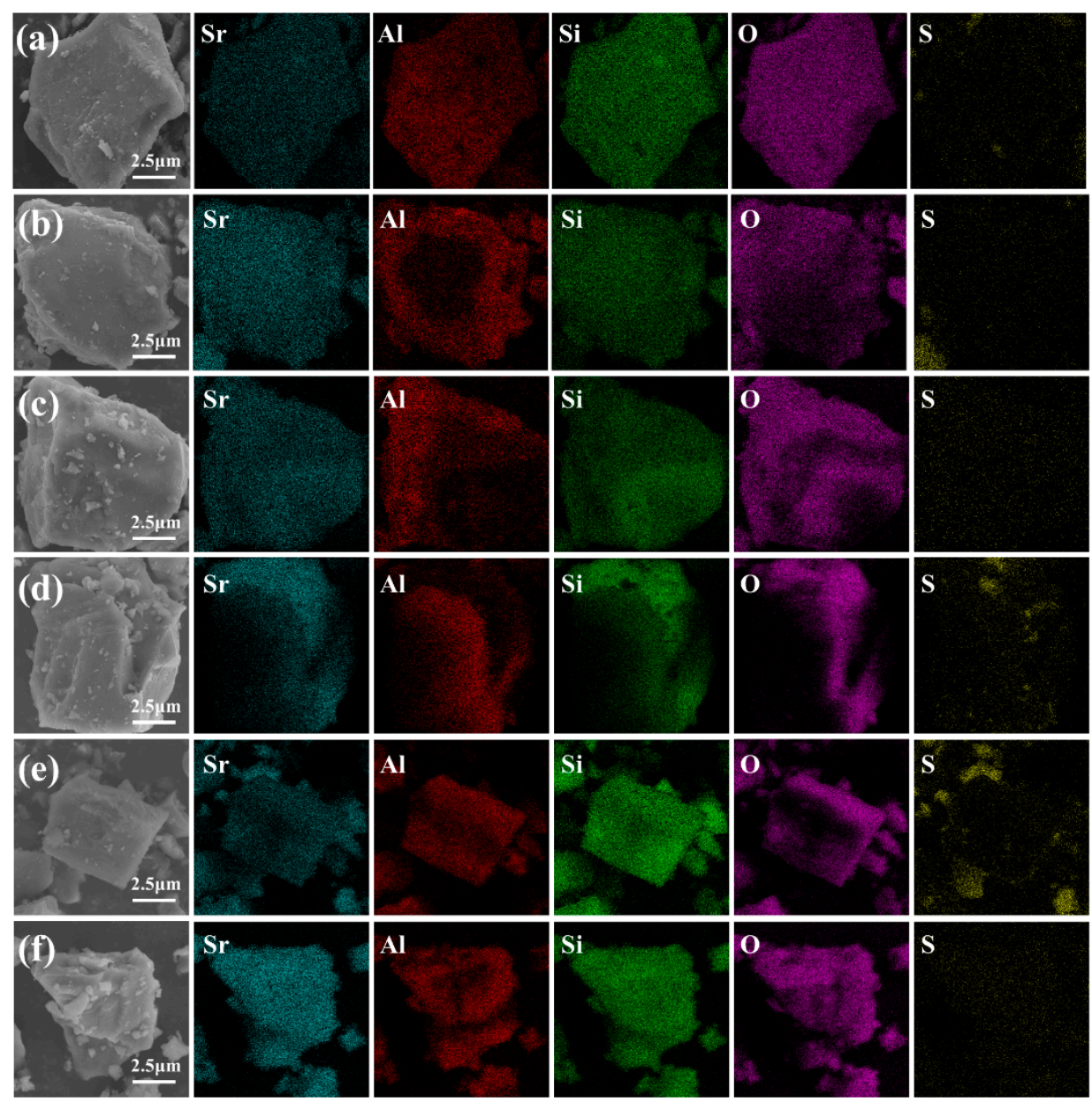

Figure 6. Elemental distribution of the sintered samples: (a) $1100{ }^{\circ} \mathrm{C}, 20 \mathrm{wt} . \% \mathrm{SrSO}_{4}$, (b) $1200{ }^{\circ} \mathrm{C}$, 20 wt. $\% \mathrm{SrSO}_{4}$, (c) $1300{ }^{\circ} \mathrm{C}, 20$ wt. $\% \mathrm{SrSO}_{4}$, (d) $1100{ }^{\circ} \mathrm{C}, 30$ wt. $\% \mathrm{SrSO}_{4}$, (e) $1200{ }^{\circ} \mathrm{C}, 30$ wt. $\% \mathrm{SrSO}_{4}$, and (f) $1300{ }^{\circ} \mathrm{C}, 30 \mathrm{wt} . \% \mathrm{SrSO}_{4}$.

To obtain immobilization mechanism of strontium in the sintered bodies, the S30 sample fabricated at $1300{ }^{\circ} \mathrm{C}$ is further studied by TEM. As depicted in Figure $7 \mathrm{a}$, the sintered sample is composed of a well-developed crystal structure with a regular arrangement. The corresponding selected area electron diffraction (SAED) is presented in Figure $7 \mathrm{~b}$. According to the atom arrangement, the sample is identified as a single crystal under the high-resolution mode, which is in agreement with XRD results in Figure 3c. The SAED pattern (Figure $7 \mathrm{~b}$ indicates that the neighboring diffraction spots can be readily indexed to the $\left(\begin{array}{lll}1 & 0 & 0\end{array}\right)$ and $\left(\begin{array}{lll}0 & 10 & 0\end{array}\right)$ crystal planes of the $\mathrm{SrAl}_{2} \mathrm{Si}_{2} \mathrm{O}_{8}$ phase respectively according to the XRD standard card (PDF\# 70-1826, $\mathrm{a}=8.388 \AA, \mathrm{b}=12.974 \AA$, $\mathrm{c}=14.264 \AA, \alpha=90^{\circ}$, $\beta=115.2^{\circ}, \gamma=90^{\circ}$, space group I2/c). Moreover, the angles measured between the $\left(\begin{array}{lll}1 & 10 & 0\end{array}\right)$ crystal plane and the (1 $\left.\begin{array}{lll}1 & 0\end{array}\right)$ and $\left(\begin{array}{lll}0 & 10 & 0\end{array}\right)$ crystal planes are $80.3^{\circ}$ and $9.7^{\circ}$ respectively. The crystalline band axis of the sample can be identified as $\left(\begin{array}{lll}0 & 0 & 1\end{array}\right)$. Combined with XRD results and FT-IR results, it can be inferred that $\mathrm{Al}^{3+}$ could replace $\mathrm{Si}^{4+}$ in an ordered or non-ordered way as the ionic radius of $\mathrm{Al}^{3+}$ is similar with $\mathrm{Si}^{4+}$ in the sintering process. $\mathrm{Sr}^{2+}$ cations with positive charge could compensate the charge difference caused by the substitution of $\mathrm{Al}^{3+}$ for $\mathrm{Si}^{4+}$ as well as react with $\mathrm{Al}^{3+}$ and $\mathrm{Si}^{4+}$ to form $\mathrm{SrAl}_{2} \mathrm{Si}_{2} \mathrm{O}_{8}$. It is worth to mention that the sintering temperature is conducive to improve the solid solution of $\mathrm{SrSO}_{4}$. The crystallographic information of $\mathrm{SrAl}_{2} \mathrm{Si}_{2} \mathrm{O}_{8}$ is demonstrated in Figure 7c. 

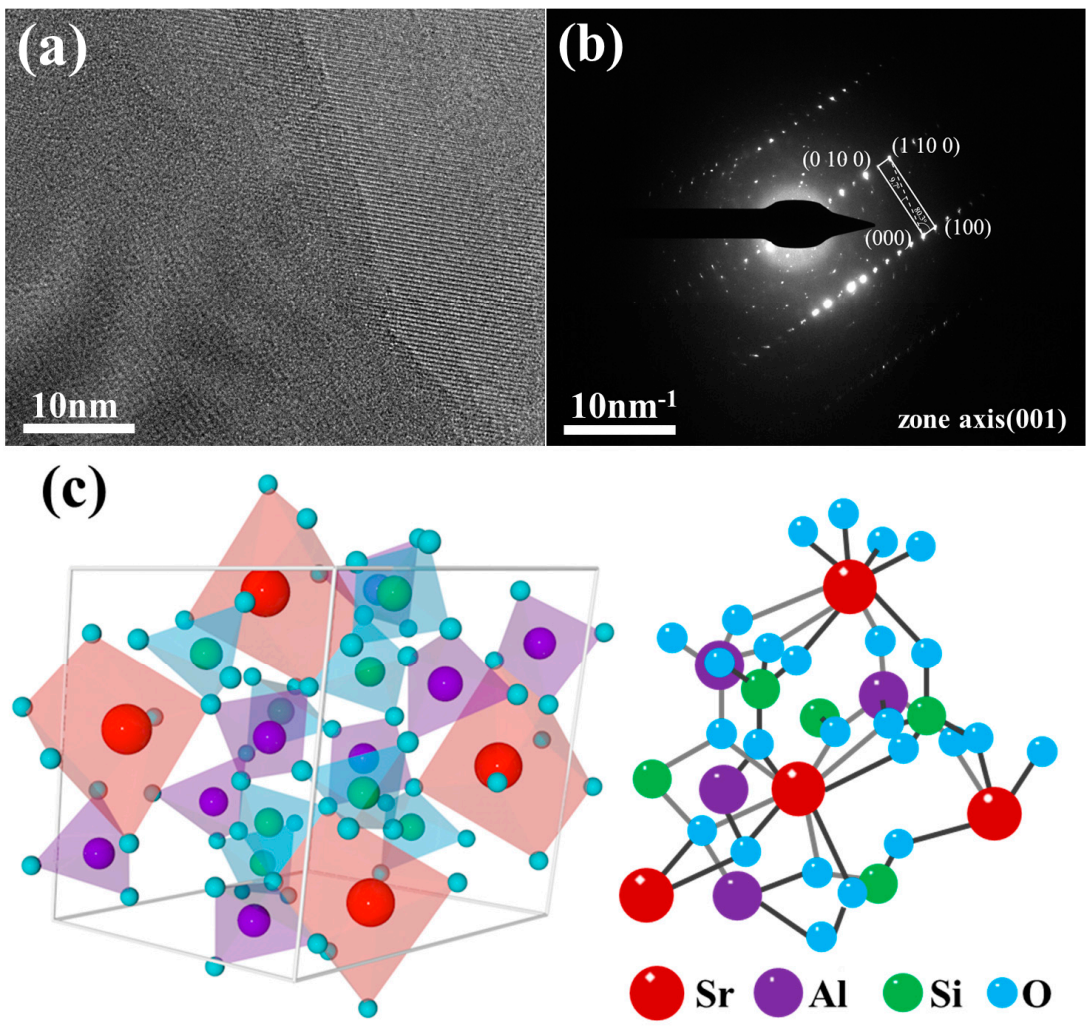

Figure 7. TEM image (a) and SAED pattern (b) of S30 sintered at $1300^{\circ} \mathrm{C}$, and (c) crystallographic information of $\mathrm{SrAl}_{2} \mathrm{Si}_{2} \mathrm{O}_{8}$.

\subsection{Physical Property Analysis}

Figure 8 shows the density and open porosity of typical samples sintered at $1100{ }^{\circ} \mathrm{C}$, $1200{ }^{\circ} \mathrm{C}$, and $1300^{\circ} \mathrm{C}$. It can be found that the density of all sintered samples increases with an elevated doping amount of $\mathrm{SrSO}_{4}$. When the doping amount is $30 \mathrm{wt} . \%$ and the sintering temperature reaches $1200^{\circ} \mathrm{C}$, the density reaches the maximum value $\left(2.53 \mathrm{~g} / \mathrm{cm}^{3}\right)$, which satisfies the density requirement of radioactive waste packages $\left(>2.5 \mathrm{~g} / \mathrm{cm}^{3}\right)$ [25]. However, when the doping amount of $\mathrm{SrSO}_{4}$ is below $25 \mathrm{wt} . \%$, the density of all sintered samples decreases with the increase of sintering temperature. It might be ascribed to the increasing involvement of $\mathrm{Sr}^{2+}$ in the reaction with $\mathrm{Al}^{3+}$ and $\mathrm{Si}^{4+}$ to form the $\mathrm{SrAl}_{2} \mathrm{Si}_{2} \mathrm{O}_{8}$ as the temperature increases which leads to more vacancies. It is in agreement with above XRD and FT-IR results. The open porosity of all sample is maintained at a relative high level, which is attributed to the presence of carbon and volatiles in the CFA. With the increase of sintering temperature, the open porosity decreases, implying that the elevation of sintering temperature is conducive to densification. 


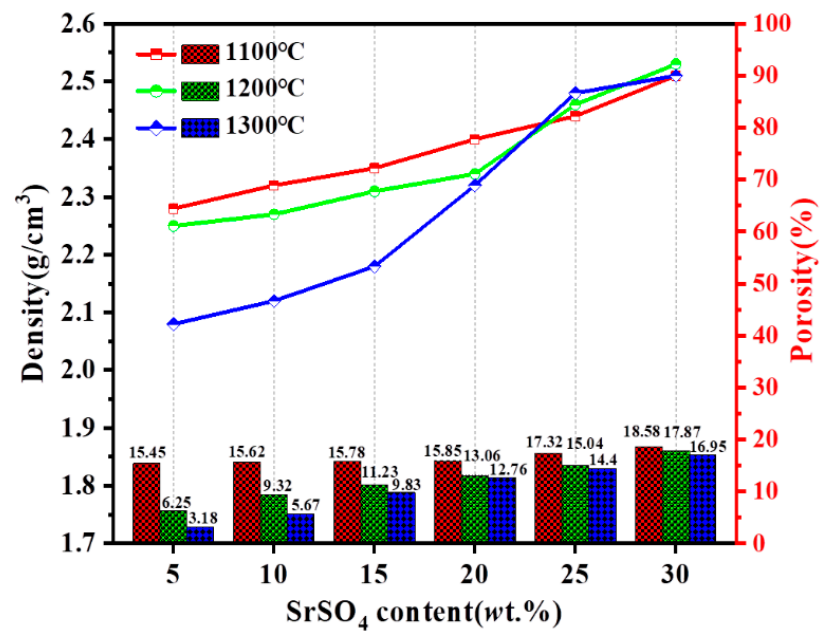

Figure 8. Density and porosity of the typical samples sintered at various temperature.

\section{Conclusions}

In the present work, a series of Sr-contaminated soil were immobilized by using CFA as raw material via microwave sintering. The phase evolution, microstructural, and micromorphology analysis results show that the more than $30 \mathrm{wt} . \% \mathrm{SrSO}_{4}$ can be accommodated into feldspar strontian $\left(\mathrm{SrAl}_{2} \mathrm{Si}_{2} \mathrm{O}_{8}\right)$ at $1300{ }^{\circ} \mathrm{C}$, and the elements are homogeneously distributed in the sintered matrices without substantial enrichment. The density and porosity tests show that the sintered sample fabricated at $1300{ }^{\circ} \mathrm{C}$ has good physical stability. Therefore, the CFA could be an ideal alternative raw material for the disposal of Sr-contaminated soil via microwave sintering.

Author Contributions: Y.X.: Methodology, Conceptualization, Writing-original draft, Funding acquisition. A.Z.: Validation, Data curation. M.C.: Software, Conceptualization. B.D.: Investigation, Resources. B.W.: Characterization, Formal analysis. Y.L.: Project administration, Funding acquisition. All authors have read and agreed to the published version of the manuscript.

Funding: This research was funded by the research and Development Program in Key Areas of Hunan Province (No. 2019SK2011), Hunan Provincial Innovation Foundation for Postgraduate (No. CX20210915), and the Natural Science Foundation of Hunan Province (No. 2019JJ50497).

Institutional Review Board Statement: Not applicable.

Informed Consent Statement: Not applicable.

Data Availability Statement: Data are available upon reasonable request to corresponding authors at xieyupeng@usc.edu.cn (Y.X.)

Acknowledgments: We acknowledge financial support from China Hunan provincial science and technology department and Hunan provincial department of education. We are thankful to the reviewers for their valuable comments and suggestions.

Conflicts of Interest: All authors declare that they have no financial interest and personal relationships with other people or organizations that can influence the work reported in this paper. University of South China and the Hunan NO.4 Engineering Co., LTD have only scientific cooperation and no commercial cooperation.

\section{References}

1. Wei, Y.F.; Luo, P.; Wang, J.X.; Wen, J.W.; Zhan, L.; Zhang, X.; Yang, S.Y.; Wang, J. Microwave-sintering preparation, phase evolution and chemical stability of $\mathrm{Na}_{1-2 \mathrm{x}} \mathrm{Sr}_{\mathrm{x}} \mathrm{Zr}_{2}\left(\mathrm{PO}_{4}\right)_{(3)}$ ceramics for immobilizing simulated radionuclides. J. Nucl. Mater. 2020, 540, 152366. [CrossRef]

2. Weber, J.W.; Navrotsky, A.; Stefanovsky, S.; Vance, E.R.; Vernaz, E. Materials science of high-level nuclear waste immobilization. MRS Bull. 2009, 34, 46-53. [CrossRef] 
3. Tang, H.; Shu, X.; Huang, W.; Miao, Y.; Shi, M.; Chen, S.; Li, B.; Luo, F.; Xie, Y.; Shao, D.; et al. Rapid solidification of Srcontaminated soil by consecutive microwave sintering: Mechanism and stability evaluation. J. Hazard. Mater. 2021, $407,124761$. [CrossRef] [PubMed]

4. Yasunari, T.J.; Stohl, A.; Hayano, R.S.; Burkhart, J.F.; Eckhardt, S.; Yasunari, T. Cesium-137 deposition and contamination of Japanese soils due to the Fukushima nuclear accident. Proc. Natl. Acad. Sci. USA 2013, 108, 19530-19534. [CrossRef] [PubMed]

5. Kato, H.; Onda, Y.; Teramage, M. Depth distribution of ${ }^{137} \mathrm{Cs},{ }^{134} \mathrm{Cs}$, and ${ }^{131} \mathrm{I}$ in soil profile after Fukushima Dai-ichi Nuclear Power Plant Accident. J. Environ. Radioact. 2012, 111, 59-64. [CrossRef] [PubMed]

6. Ojovan, M.I.; Lee, W.E. Glassy Wasteforms for Nuclear Waste Immobilization. Metall. Mater. Trans. A 2010, 42, 837-851. [CrossRef]

7. Gin, S.; Jollivet, P.; Tribet, M.; Peuget, S.; Schuller, S. Radionuclides containment in nuclear glasses: An overview. Radiochim. Acta 2017, 105, 927-959. [CrossRef]

8. Meng, C.; Li, W.Q.; Ren, C.R.; Zhao, J.C. Structure and chemical durability studies of powellite ceramics $\mathrm{Ca}_{1-\mathrm{x}} \mathrm{Li}_{\mathrm{x} / 2} \mathrm{Gd}_{\mathrm{x} / 2} \mathrm{MoO}_{4}$ $(0 \leq \mathrm{x} \leq 1)$ for radioactive waste storage. J. Mater. Sci. 2020, 55, 2741-2749. [CrossRef]

9. Donald, I.W.; Metcalfe, B.L.; Taylor, R.N.J.J.J.o.M.e. The immobilization of high level radioactive wastes using ceramics and glasses. J. Mater. Sci. 1997, 32, 5851-5887. [CrossRef]

10. Li, Y.; Feng, J.; Wang, Y.; Cheng, X. Preparation of Mullite Ceramics with Fly Ash and Clay by Pickling Process. Int. J. Appl. Ceram. Technol. 2015, 12, E132-E137. [CrossRef]

11. Blissett, R.S.; Rowson, N.A. A review of the multi-component utilisation of coal fly ash. Fuel 2012, 97, 1-23. [CrossRef]

12. Luo, Y.; Ma, S.; Liu, C.; Zhao, Z.; Zheng, S.; Wang, X. Effect of particle size and alkali activation on coal fly ash and their role in sintered ceramic tiles. J. Eur. Ceram. Soc. 2017, 37, 1847-1856. [CrossRef]

13. Zimmer, A.; Bergmann, C.P. Fly ash of mineral coal as ceramic tiles raw material. Waste Manag. 2007, 27, 59-68. [CrossRef]

14. Wei, G.; Shi, M.; Xu, C.; Shu, X.; Luo, F.; Chen, S.; Wang, L.; Xie, Y.; Lu, X. Mechanical and leaching properties of neodymiumcontaminated soil glass-ceramics. J. Am. Ceram. Soc. 2021, 104, 2521-2529. [CrossRef]

15. Tu, H.; Duan, T.; Ding, Y.; Lu, X.; Tang, Y.; Li, Y. Preparation of zircon-matrix material for dealing with high-level radioactive waste with microwave. Mater. Lett. 2014, 131, 171-173. [CrossRef]

16. Zhang, S.; Ding, Y.; Lu, X.; Mao, X.; Song, M. Rapid and efficient disposal of radioactive contaminated soil using microwave sintering method. Mater. Lett. 2016, 175, 165-168. [CrossRef]

17. Zhang, S.; Shu, X.; Chen, S.; Yang, H.; Hou, C.; Mao, X.; Chi, F.; Song, M.; Lu, X. Rapid Immobilization of Simulated Radioactive Soil Waste by Microwave Sintering. J. Hazard. Mater. 2017, 337, 20-26. [CrossRef]

18. Shu, X.; Li, Y.; Huang, W.; Chen, S.; Lu, X. Rapid vitrification of uranium-contaminated soil: Effect and mechanism. Environ. Pollut. 2020, 263, 114539. [CrossRef]

19. Oghbaei, M.; Mirzaee, O. Microwave versus conventional sintering: A review of fundamentals, advantages and applications. $J$. Alloys Compd. 2010, 494, 175-189. [CrossRef]

20. Jiang, Z.; Xiong, T.; Bai, Z.; Zhao, D.; Yang, W.; Peng, Y.; Dan, H.; Ding, Y.; Duan, T. Effect of Si/Zr molar ratio on the sintering and crystallization behavior of zircon ceramics. J. Eur. Ceram. Soc. 2020, 40, 4605-4612. [CrossRef]

21. MacDonald, S.A.; Schardt, C.R.; Masiello, D.J.; Simmons, J.H. Dispersion analysis of FTIR reflection measurements in silicate glasses. J. Non-Cryst. Solids 2000, 275, 72-82. [CrossRef]

22. El-Egili, $\mathrm{K}$. Infrared studies of $\mathrm{Na}_{2} \mathrm{O}-\mathrm{B}_{2} \mathrm{O}_{3}-\mathrm{SiO}_{2}$ and $\mathrm{Al}_{2} \mathrm{O}_{3}-\mathrm{Na}_{2} \mathrm{O}-\mathrm{B}_{2} \mathrm{O}_{3}-\mathrm{SiO}_{2}$ glasses. Phys. B Condens. Matter 2003, 325, 340-348. [CrossRef]

23. Mrosko, M.; Koch-Muller, M.; Schade, U. In-situ mid/far micro-FTIR spectroscopy to trace pressure-induced phase transitions in strontium feldspar and wadsleyite. Am. Mineral. 2011, 96, 1748-1759. [CrossRef]

24. Manam, J.; Das, S. Preparation, characterization and thermally stimulated luminescence studies of undoped, Cu and Mn doped $\mathrm{SrSO}_{4}$ compounds. Opt. Mater. 2009, 31, 1231-1241. [CrossRef]

25. Ahn, J. Characterization of radioactive waste forms and packages: Technical Reports Series No. 383, International Atomic Energy Agency, Vienna, 1997, 138 pages, ISBN 92-0-100497-4, US\$ 55. Waste Manag. 1998, 18, 62. [CrossRef] 